Northwestern University School of Law

Northwestern University School of Law Scholarly Commons

Faculty Working Papers

2010

\title{
Federal Circuit Patent Precedent: An Empirical Study of Institutional Authority and IP Ideology
}

David Pekarek-Krohn

Northwestern University School of Law

Emerson H. Tiller

Northwestern University School of Law, tiller@law.northwestern.edu

\section{Repository Citation}

Pekarek-Krohn, David and Tiller, Emerson H., "Federal Circuit Patent Precedent: An Empirical Study of Institutional Authority and IP Ideology" (2010). Faculty Working Papers. Paper 42.

http://scholarlycommons.law.northwestern.edu/facultyworkingpapers/42 


\title{
Federal Circuit Patent Precedent: An Empirical Study of Institutional Authority and IP Ideology
}

\author{
David R. Pekarek Krohn \\ Emerson H. Tiller \\ Northwestern University School of Law
}

\begin{abstract}
I. INTRODUCTION
The Court of Appeals for the Federal Circuit (the Federal Circuit) is unique among the circuit courts of appeals because it has nationwide jurisdiction over certain subject matter, including patents. ${ }^{1}$ Because of this jurisdictional exclusivity, there is no opportunity for a "circuit split" on patent law, and the main conversation is between the Federal Circuit and the Supreme Court. ${ }^{2}$ The Progress Clause makes clear that there is a balancing act involved in intellectual property, where the government exchanges public access for the public good. ${ }^{3}$ Recent landmark Supreme Court reversals of the Federal Circuit highlight these courts' different views of where this balance should be in the patent context, with the Federal Circuit being more protective of patent rights as property than the Supreme Court. ${ }^{4}$ The involvement by the Supreme Court was not completely welcomed by the patent bar. ${ }^{5}$
\end{abstract}

${ }^{1} 28$ U.S.C. $§ 1295(a)(1)$ (2006). See also Holmes Group, Inc. v. Vornado Air Circulation Systems, Inc., 535 U.S. 826 (2002); http://www.cafc.uscourts.gov/about.html. For more on the Federal Circuit and how it is "succeeding," see R. Polk Wagner \& Lee Petherbridge, Is the Federal Circuit Succeeding? An Empirical Assessment of Judicial Performance, 152 U. PA. L. REV. 1105 (2004).

${ }^{2}$ See, e.g., Wagner \& Petherbridge, supra note 1 (noting that "the United States Court of Appeals for the Federal Circuit has become, by far, the most powerful and influential force in the U.S. patent system."); The Honorable Timothy B. Dyk, Does The Supreme Court Still Matter?, 57 Am. U. L. Rev. 763, 764 (2008) (foreward by Federal Circuit Judge to a review of decisions by the Federal Circuit and noting the recent increase of grant of certiorari by the Supreme Court of Federal Circuit patent decisions).

${ }^{3}$ U.S. Const. art. I, $\S 8$, cl. 8 (Granting congress the power "To promote the Progress of Science and useful Arts, by securing for limited Times to Authors and Inventors the exclusive Right to their respective Writings and Discoveries").

${ }^{4}$ See Festo Corp. v. Shoketsu Kinzoku Kogyo Kabushiki Co., 535 U.S. 722 (2002) (where a unanimous Supreme Court struck down a rule regulating patent scope that had been adopted by the Federal Circuit en banc); eBay Inc. v. MercExchange, L.L.C., 547 U.S. 388 (2006) (unanimous Supreme Court vacating part of a Federal Circuit panel decision that had reversed a district court's denial of a permanent injunction); KSR International Co. v. Teleflex Inc., 127 S. Ct. 1727 (2007) (unanimous Supreme Court reversing a panel decision because the panel had analyzed the nonobviousness of a claimed invention in an overly "rigid" way). Quanta Computer, Inc. v. LG Electronics, Inc., 128 S. Ct. 2109 (2008) (unanimous Supreme Court reversing Circuit panel with respect to its understanding and application of the doctrine that patent rights are exhausted by an authorized first sale). See also, Craig Allen Nard and John C. Duffy, Rethinking Patent Law's Uniformity Principle, 101 Nw. U. L. Rev. 1619, 1621 (2007) (Solicitor General and the United States Patent and Trademark Office (PTO) represented to the Supreme Court that the Federal Circuit's test of patentability--a centerpiece of the circuit's patent jurisprudence for more than twenty years--is "misguided" and "counterproductive" and has "exact[ed] a heavy cost in the form of unwarranted extension of 
Federal district courts are on the front line of patent disputes and are subject to the doctrines and review of the Federal Circuit. Recent empirical studies of district court patent decisions show that the establishment and jurisprudence of the Federal Circuit has led to more pro-patent decisions by district courts - at least with respect to issues of patent validity - than had been the case prior to the Federal Circuit's creation, ${ }^{6}$ suggesting that the Federal Circuit's pro-patent perspective has been carried out in mass by the lower courts. ${ }^{7}$ The lack of such effects on district court infringement outcomes, however, suggests that the pro-patent bias of the Federal Circuit may not be as pervasive as some believe. ${ }^{8}$

Examining district court outcomes on patent validity and infringement issues is one way to examine the influence of the Federal Circuit. Indeed, most studies of judicial behavior focus on case outcome (who wins and who loses in a case) as the central measure of court ideology and influence. ${ }^{9}$ Recently, scholars have looked more closely at opinion content-what judges say and how they reason in the opinion-to help explain other aspects of judicial behavior. Some studies, for example, have considered various decision instruments (such as fact-finding, statutory interpretation, or constitutional review discussions in judicial opinions) as measures of strategic decision making (as when courts attempt to avoid overrides by legislatures or higher courts by choosing among decision instrument alternatives). ${ }^{10}$ Other studies have examined citations to cases and legislative history to find a variety of characteristics associated with judicial decision making. Some of these studies are used to illustrate the quality of particular

patent protection. ...") (quoting Brief for the United States as Amicus Curiae Supporting Petitioner at 10, 16, KSR Int'l Co. v. Teleflex Inc., 127 S. Ct. 1727 (2007) (No. 04-1350).

${ }^{5}$ See Dyk, supra note 2, at 763 ("At any gathering of the [patent] bar, no tag line of a speech has more assurance of applause than one that importunes the Supreme Court to keep its hands off the patent law.").

${ }^{6}$ Matthew D. Henry and John L. Turner, The Court of Appeals for the Federal Circuit's Impact on Patent Litigation, 35 J. Legal Studies 85 (2006).

${ }^{7}$ See Kathleen M. O'Malley, Patti Saris \& Ronald H. Whyte, A Panel Discussion: Claim Construction from the Perspective of the District Judge, 54 Case W. Res. L. Rev. 671, 673 (2004) (O'Malley, J., stating that "[w]ithin the realm of patent law, the [Federal Circuit] has had, in [district court judges'] view, its biggest impact in the claim construction area");

${ }^{8}$ See John M. Golden, The Supreme Court as Prime "Percolator": A Prescription for Appellate Review of Questions in Patent Law, 56 UCLA L. Rev. 657 (2009) at 679 (“... this apparently pro-patent shift appears to have been accompanied by an effort to take a more restrictive approach to patent breadth. Under the Federal Circuit, patents may be more likely to be issued and upheld, but they may also be more likely to have a relatively narrow scope."); Donald S. Chisum, The Supreme Court and Patent Law: Does Shallow Reasoning Lead to Thin Law, 3 Marq. Intell. Prop. L. Rev. 1 (1999) (asserting that Federal Circuit precedent has made it more difficult to establish infringement); and Arti K. Rai, Engagin Facts and Policy: A Multi-Institutional Approach to Patent System Reform, 103 Colum. L. Rev. 1035, 1112 (2003) (concluding that "the court has clearly not accepted the most assertive version of patents-asordinary-property claim, which counsels in favor of broad grants")

${ }^{9}$ See, e.g., Jeffrey A. Segal \& Harold Spaeth, The Supreme Court and the Attitudinal Model (1993); Sheldon Goldman, Voting Behavior on the United States Court of Appeals, 1961-1964, 60 Am. J. Pol. Sci. 374 (1966); Matthew Sag, Tonja Jacobi and Maxim Sytch, Ideology and Exceptionalism in Intellectual Property: An Empirical Study, 97 Cal. L. Rev 801 (2009).

${ }^{10}$ Pablo T. Spiller and Matthew Spitzer, Judicial Choice of Legal Doctrines, 8 J. L. Econ. \& Org. 8 (1992); Emerson H. Tiller and Pablo T. Spiller, Strategic Instruments: Legal Structure and Political Games in Administrative Law, 15 J. L. Econ. \& Org. 349 (1999); Joseph L. Smith and Emerson H. Tiller, The Strategy of Judging; Evidence from Administrative Law, 31 J. Legal Studies 61 (2002); Max M. Schanzenbach and Emerson H. Tiller, Strategic Judging under the United States Sentencing Guidelines: Positive Political Theory and Evidence. 23 J. L. Econ. \& Org. 24 (2007). 
judges or courts through the citation rate of opinions they have authored, ${ }^{11}$ while others suggest that citation to legislative history by judges is used to strategically influence co-panelists on a court. $^{12}$

In this paper, we aim to better understand the institutional authority of the Federal Circuit as a source of law as well as the influence of pro-patent and anti-patent ideological forces at play between the Supreme Court, Federal Circuit, and the district courts. Our specific focus is on the district courts and how they cite Federal Circuit precedent relative to Supreme Court precedent to support their decisions, whether they be pro-patent or anti-patent. Thus, we are as interested in opinion content as we are in case outcomes. Our inquiry is fairly simple: First, if the Federal Circuit has achieved the authority over patent jurisprudence that was expected by the legislature that created it, we should expect citation to Federal Circuit cases by lower courts to be fairly large and uniform when compared to citation to Supreme Court precedent-the only other court with reviewing authority over the lower courts' patent decisions. We should also expect the Federal Circuit's authority to result in a tighter citation relationship between district courts and the Federal Circuit than the citation relationship between district courts and their regional circuit courts in other areas of law (e.g., copyright). Second, if the Federal Circuit has exhibited a consistent pro-patent bias, we should see that bias reflected-through an increase in the use of citations to Federal Circuit precedent compared to Supreme Court precedent-in district court opinions upholding patent rights as compared to district court opinions not upholding patent rights.

Using a variety of citation approaches and statistical tests, we find that federal district courts treat the Federal Circuit as more authoritative (compared to the Supreme Court) on patent law, than they treat the regional circuits (compared to the Supreme Court) on copyright law. Second, the Federal Circuit's precedent tends to be relied on more in pro-patent opinions than in anti-patent opinions. ${ }^{13}$ In addition, both of these effects are stronger in how the district courts use the precedent-i.e., how many times precedent is cited - than in what higher court precedent is used.

\section{BACKGROUND}

Studying the influence of the Federal Circuit on district court patent case decision making seems appropriate given the purpose behind the Federal Circuit's creation-that is, to create uniformity in patent law. ${ }^{14}$ That was an important goal given that some circuit courts were regarded as "pro-patent" and others "anti-patent," and much time and money was expended in "shopping" for a favorable venue. ${ }^{15}$ While forum shopping in patent cases continues, it is based more on the local rules of specific districts, and not on the substantive law

${ }^{11}$ Stephen J. Choi and G. Mitu Gulati, Choosing the Next Supreme Court Justice: An Empirical Ranking of Judicial Performance, 78 S. Cal Law Rev. 23 (2004); Stephen J. Choi, Mitu Gulati, and Eric A. Posner, Judicial Evaluations and Information Forcing: Ranking State High Courts and Their Judges, 58 Duke L. J. 1313 (2009).

${ }^{12}$ Michael Abramowicz and Emerson H. Tiller, Citation to Legislative History: Empirical Evidence on Positive Political and Contextual Theories of Decisionmaking, 38 J. Leg. Studies 419 (2009).

${ }^{13}$ When we refer to an opinion as pro-patent or pro-copyright, we specifically mean that the ruling in the opinion favored the patent or copyright owner over the other party.

${ }^{14}$ See S. Rep. No. 97-275, at 5 (1981) ("The creation of the Court of Appeals for the Federal Circuit will produce desirable uniformity in this area of ... [patent] law.").

${ }^{15}$ H.R. Rep. No. 97-312, at 20-21 (1981) (noting that "some circuit courts are regarded as 'pro-patent' and others 'anti-patent,' and much time and money is expended in 'shopping' for a favorable venue"). 
of the circuit. To be sure, there is much debate about the Federal Circuit's role, especially regarding the centralized institutional authority over patent law that is part of the Federal Circuit's design. There is also some debate about whether the Federal Circuit is as pro-patent in its decisions and doctrines as alleged by its critics.

Professors Nard and Duffy criticize the uniformity of law inherent in the structure of the Federal Circuit, noting that "the normal back-and-forth dialogue between peer judicial institutions largely has evaporated from U.S. patent law." According to Nard and Duffy, without the benefits of competition and diversity, the Federal Circuit is not exposed to worthwhile doctrinal proposals and normative prescriptions generated by other circuit courts. They argue that "it is at the appellate level where these proposals and prescriptions can make the most pronounced difference." Incremental innovativeness and adaptiveness- "two ingredients that sustain any area of the law"-are lost, they argue. Professor John Golden likewise argues that centralizing appellate review in the Federal Circuit has made patent law unusually susceptible to doctrinal ossification. ${ }^{16} \mathrm{He}$ argues, however, that the problem is not so dire, suggesting that by "engaging in periodic merits review of patent law doctrines that the Federal Circuit may have locked into place either too quickly or for too long, the Supreme Court can help initiate escapes from suboptimal legal equilibria." He points to the recent Supreme Court patent decisions where in the last ten terms, "the Supreme Court has affirmed the Federal Circuit's decisions in only two patent cases, vacated the Circuit's decisions in four, and reversed the Circuit's decisions in six. All four of the most recently decided cases ended in a reversal." 17

Other scholars have been concerned that the centralization of patent law authority in the Federal Circuit would lead to "capture" by pro-patent interests. ${ }^{18}$ Whether or not "capture" has occurred, there is much commentary that the Federal Circuit has been a pro-patent court, even more pro-patent than some of the regional courts had been prior to the creation of the Federal Circuit. ${ }^{19}$ But others argue that the apparently pro-patent shift has been accompanied by a more restrictive approach to patent breadth. One commentator suggested that "[u]nder the Federal

\footnotetext{
${ }^{16}$ John M. Golden, The Supreme Court as Prime "Percolator": A Prescription for Appellate Review of Questions in Patent Law, 56 UCLA L. Rev. 657 (2009)

${ }^{17} I d$ at 671 .

${ }^{18}$ Stuart Minor Benjamin \& Arti K. Rai, Fixing Innovation Policy: A Structural Perspective, 77 Geo. Wash. L. Rev. 1_(2008) (concluding that the Federal Circuit's behavior was "arguably consistent with standard accounts of capture of regulatory processes by well-represented interest groups"); John R. Thomas, Formalism at the Federal Circuit, 52 AM. U. L. REV. 771, 792-94 (2003) (discussing how the Federal Circuit's "jurisprudence increasingly reflects a trend towards adjudicative rule formalism," which is explained in part as a response to the "lawyers [who] draft the exclusionary rules that are patent claims").

${ }^{19}$ James Bessen \& Michael J. Meurer, Patent Failure: How Judges, Bureaucrats, and Lawyers Put Innovators at Risk 25 (2008) at 69 (citing various studies suggesting a "pro-patent" shift in the law); Adam B. Jaffe \& Josh Lerner, Innovation and Its Discontents: How Our Broken Patent System Is Endangering Innovation and Progress, and What to Do About It 110 (2004) (stating that the Federal Circuit's rules "have been systematically altered in favor of the patent holders"); William M. Landes \& Richard A. Posner, The Economic Structure of Intellectual Property Law (2003) (stating that "[t]he Federal Circuit has indeed turned out to be a pro-patent court"); John R. Allison \& Mark A. Lemley, Empirical Evidence on the Validity of Litigated Patents, 26 AIPLA Q.J. 185, 251 (1998) (concluding that findings of patent validity have been significantly higher since the establishment of the Federal Circuit); Robert P. Merges, Commercial Success and Patent Standards: Economic Perspectives on Innovation, 76 CAL. L. REV. 803, 822 (1988) ("Even with the[] safeguards, [Congress imposed when it created the Federal Circuit, the Federal Circuit appears to be a 'pro-patent' court.").
} 
Circuit, patents may be more likely to be issued and upheld, but they may also be more likely to have a relatively narrow scope."20

With respect to issues of patent validity, at least one study suggests that uniformity has occurred. In their study of district court patent opinions, Professors Henry and Turner find that because of the Federal Court's tendencies, "district courts have been roughly half as likely to issue a decision of invalidity, patentees have been about 25 percent more likely to appeal these decisions, and the appeals court has been nearly three times more likely to not affirm a decision of invalidity." 21 According to Henry and Turner, "the timing, synchronicity, and intuitive consistency of these breaks are strong evidence that the [Federal Circuit's] stronger presumption of validity has had a significant impact on these probabilities." 22 Other scholars, however, have concluded that the pro-patent bias does not exist. ${ }^{23}$

Given the debates about whether there is a pro-patent bias, and whether the centralization of patent law and has been attenuated by a more active Supreme Court, information about district court citations to Federal Circuit and Supreme Court decisions may add value. Citation measures can help show to whom a district court gives greater respect and authority in making its decisions, and whether such respect and authority is related to propatent or anti-patent outcomes.

\section{HOW WE ARE TESTING THE STORY}

\section{A. Hypotheses \\ 1. The Federal Circuit is More Authoritative Than The Regional Circuits}

The Federal Circuit was created to provide a uniform authority for patent law. It has been called by some the "Supreme Court of Patents." 24 Given this directive by Congress, one might expect district courts to treat the Federal Circuit as more authoritative in patent law than the controlling regional circuit courts would be in other areas of law. The reason is that in other areas of law (e.g., copyright), a district court would view the Supreme Court as substantially more authoritative than the regional court (compared to the Federal Circuit and its relation to the Supreme Court in the area of patent law). In addition, the district court may consider opinions in other circuits making decision in the same area of law that can legitimately

${ }^{20}$ John M. Golden, The Supreme Court as Prime "Percolator": A Prescription for Appellate Review of Questions in Patent Law, 56 UCLA L. Rev. 657 (2009)

21 Matthew D. Henry and John L. Turner, The Court of Appeals for the Federal Circuit's Impact on Patent Litigation, 35 J. Legal Studies 85 at 90 (2006).

22 Matthew D. Henry and John L. Turner, The Court of Appeals for the Federal Circuit's Impact on Patent Litigation, 35 J. Legal Studies 85 (2006).

${ }^{23}$ Glynn S. Lunney, Jr., Patent Law, the Federal Circuit, and the Supreme Court: A Quiet Revolution, 11 Sup. Ct. Econ. Rev. 1, 3 (2004) ( "Despite the Federal Circuit's pro-patent holder reputation[,] claims of patent infringement are no more likely to succeed since the Federal Circuit's advent."); Paul M. Janicke \& LiLan Ren, Who Wins Patent Infringement Cases?, 34 AIPLA Q.J. 1, 39 (2006) (claiming that their findings do not support the view that the Federal Circuit has pro-patent leanings).

${ }^{24}$ See, e.g., Mark D. Janis, Patent Law in the Age of the Invisible Supreme Court, 2001 U. ILL. L. REV. 387,387 ("The Court of Appeals for the Federal Circuit . . . has become the de facto supreme court of patents"); Kimberly Moore, Are District Court Judges Equipped to Resolve Patent Cases?, 15 HARV. J.L. \& TECH. 1, 18 n.70 (2001) (quoting Matt Krantz, Computer \& Technology Patent Suits Try Patience Of High-Tech Companies, InVESTOR'S Bus. DAILY, Dec. 9, 1996, at A6, ("The U.S. Court of Appeals for the Federal Circuit in Washington, D.C., is known as the Supreme Court of Patents. It's manned by three judges with both legal and scientific training."). 
be cited as persuasive authority (especially if facts can be distinguished from the controlling regional circuit's precedents). Regional circuit precedent is virtually non-existent for district courts making patent decisions. The decision, therefore, in choosing proper precedent is between the Federal Circuit and the Supreme Court. The specialized nature of the Federal Circuit suggests that both district courts and the Supreme Court owe it a greater level of deference than normally attributed to regional circuit courts.

Thus, the first hypothesis tests whether the Federal Circuit is viewed by the district courts as more authoritative by comparing how district court patent opinions reference and rely on Federal Circuit precedent to how district court opinions in another area of law (i.e., copyright) rely on regional circuit precedent. In both the patent and the copyright context, the circuit precedent is matched against the Supreme Court precedent in the opinion. The hypothesis is that patent opinions should rely more heavily on Federal Circuit precedent than copyright opinions do on regional circuit precedent.

Copyright is used as a comparison for a number of reasons. First, it falls within the broader area of intellectual property and they share similar ideological and policy concerns. Second, there is a sufficient number of opinions in the Supreme Court and, for the most part, the controlling regional circuit courts for a such worthwhile empirical testing. Third, patent and copyright opinions can be consistently coded as for or against the owner. We acknowledge that there are differences in patent and copyright law that go beyond which circuit is authoritative (e.g, more patent precedent from the Federal Circuit for the district court to choose from compared to any controlling regional circuit court). In addition, there are differences between the Federal Circuit and the regional circuits that go beyond what type of cases they hear. We have attempted to address these concerns through the use of multiple measures and attempting to verify our results through a variety of tests.

\section{The Federal Circuit is More Pro-Ownership Than the Supreme Court}

There is a general belief that the Federal Circuit is more pro-ownership than the Supreme Court. As discussed above, this belief is based, at least in part, on the possibility of "capture" of the Federal Circuit by pro-patent interests. ${ }^{25}$ The breadth of this bias, however, is in dispute. $^{26}$

The second hypothesis tests whether such an effect is seen through the citations to the two institutions. Specifically, the hypothesis is that, compared to anti-patent district court opinions, pro-patent district court opinions should rely more on Federal Circuit precedent (compared with Supreme Court precedent).

\section{B. Selection}

This study involves an analysis of district court patent and copyright opinions from federal districts that had high rates of patent cases. ${ }^{27}$ We randomly selected four patent

\footnotetext{
25 See supra note 18 and accompanying text.

${ }^{26}$ See supra note 19-20 and accompanying text.

27 The districts are E.D. Texas, D. Delaware, C.D. California, N.D. California, N.D. Illinois, D. New Jersey, S.D. New York. These districts were picked based on a review of the top patent jurisdictions from PATracer.com. The decision to examine opinions from districts with a lot of patent cases was deliberate. There might be a concern with selection effects if were concerned about predicting outcomes-i.e., who wins and who loses. That, however, is not our focus. Instead, we are interested in how district court judges use precedent to support their decisions, given that
} 
opinions and four copyright opinions from each district for each year for the years between 2000-2007. ${ }^{28}$ We coded these opinions for whether they were for or against the intellectual property owner. For most types of opinions, this coding was based on whether at least one motion involved in the order was granted. If it was, then it was coded as favoring the moving party. If all motions were denied, it was coded favoring the other party. For cross-motions where the decision clearly favored one party over the other, it was coded as favoring that party. For claim construction rulings, a "score" was kept of how many constructions favored each party, and the opinion was coded as favoring the "winner." In addition, some opinions were coded as unclear and others were coded as neutral, but these opinions were not used in our analysis. Opinions where the issue itself was who owned the intellectual property, as opposed to whether the owner's rights were violated by the other party, were coded as unclear. Opinions where neither party clearly benefited from the ruling (or the claim construction score was a tie) were coded as neutral. In addition, the opinions were analyzed for their citations to precedent. $^{29}$ Because some cases were not codable-either because they were incorrectly flagged as patent or copyright, or because they did not actually address an intellectual property issue - the database contains 109 copyright opinions and 141 patent opinions. To be sure, these are rough measures and they do not capture much nuance or weighting of the issues in the cases. On the other hand, the strict protocols reduced coder discretion and inconsistency.

\section{Coding}

\section{Coding and Measurements}

The opinions were coded for the following attributes:

- Year - Year opinion was decided

- District - District of case

- Judge - Author of opinion

- Magistrate - Whether the judge is a magistrate or district court judge

- Opinion Type - Type of opinion ${ }^{30}$

- Ideology - Ideology of the judge $\mathrm{e}^{31}$

they chosen a pro-patent or anti-patent outcome. What is important for our selection is that we have enough opinions to have a diversity of outcomes (patent owners and alleged infringers win often) and judicial ideology (sufficient number of liberal and conservative judges). Because the high volume districts vary on both of these, we are less concerned with any selection bias on the case characteristics of interest. In addition, of the districts identified by the recent Price Waterhouse Coopers 2009 Patent Litigation Study as the twenty most active, the districts we selected are not necessarily the most pro-owner. The study ranked them as 2nd (E.D. Texas), 3rd (D. Delaware), 5th (C.D. California), 8th (D. New Jersey), 12th (tied between N.D. California and S.D. New York), and 14th (N.D. Illinois). http://www.pwc.com/en_US/us/forensic-services/publications/assets/2009-patent-litigationstudy.pdf at 18 .

${ }^{28}$ The classification of an opinion as patent or copyright was based on being tagged by Lexis as such an opinion. Because we ended up with a low $\mathrm{N}$ after coding the first set of patent opinions, we selected another batch in the same manner. Thus, for patent opinions, we actually randomly selected eight opinions per circuit per year.

${ }^{29}$ This analysis is done using regular expression matching, This counts each case cited, as well as how many times it is cited.

${ }^{30}$ The opinions include the following types: Claim Construction, Summary Judgment, Damages, Motion to Dismiss, JMOL, Motion to Stay, Final Judgment, Preliminary Injunction, Fees and/or Sanctions, Confirmation of Arbitration Award, Motion for New Trial, Bench Trial Opinion, Permanent Injunction. 
- Is Pro Owner - A dichotomous ( 0 or 1$)$ code for who the opinion favors. A value of 1 means the opinion favored the patent/copyright owner; a value of 0 means the opinion favored the other party.

In addition, the following information was pulled from each opinion by an automated script:

- Circuit Cases - Number of circuit cases cited in the opinion (Federal Circuit for patent opinions and regional circuit for the district for copyright opinions).

- Circuit Cites - Number of cites to circuit cases in the opinion. (Federal Circuit for patent opinions, and the regional circuit for the district for copyright opinions).

- Other Circuit Cases - Number of cases from other circuits-i.e., not from Federal Circuit or regional circuit—cited in the opinion.

- Other Circuit Cites - Number of cites to cases from other circuits in the opinion.

- SCOTUS Cases - Number of Supreme Court cases cited in the opinion.

- SCOTUS Cites - Number of cites to Supreme Court cases in the opinion.

For opinions that had headnotes in Lexis, we also hand counted cases and citations within headnoted sections of the opinion related to the intellectual property discipline (patent or copyright) for the district's controlling circuit (the Federal Circuit for patent cases and the regional circuits for copyright cases), other circuits, and the Supreme Court. The purpose of this is discussed in Part III.B.2.

\section{Measurements}

We measured how the district court opinion relies on precedent in two ways. First, we measured two proportions:

$$
\begin{gathered}
\text { Case Proportion }=\frac{\text { CircuitCourtCases }}{\text { SupremeCourtCases }+ \text { CircuitCourtCases }} \\
\text { Cite Proportion }=\frac{\text { CircuitCourtCites }}{\text { SupremeCourtCites }+ \text { CircuitCourtCites }}
\end{gathered}
$$

Because these measures are proportions, they are necessarily bounded between 0 and 1 , and are reported as percentages. These proportions are defined such that the larger (more positive) the

31 Boyd, Christina L. 2009. "Federal District Court Judge Ideology Data." available at: http://cLboyd.net/ideology.html. This dataset was based on the methodology established by Giles, Michael W., Virginia A. Hettinger and Todd Peppers, Picking Federal Judges: A Note on Policy and Partisan Selection Agendas, Political Research Quarterly 54(3):623-641 (2001), as extended by Epstein, Lee, Andrew D. Martin, Jeffrey A. Segal and Chad Westerland, The Judicial Common Space, Journal of Law, Economics \& Organization, 23(2):303325 (2007). The dataset also relies on data collected from Federal Judicial Center, Federal Judges Biographical Database, http://www.fjc.gov/public/home.nsf/hisj; Poole, Keith, Common Space Scores, Congresses 75-110 (2009), available at http://voteview.com/basic.htm. See also Poole, Keith T, Estimating a Basic Space From a Set of Issue Scales, American Journal of Political Science 42:954-993 (1998). Because Magistrate Judges are not nominated by the President, they are not included in this dataset. In addition, there were 2 judges in our dataset that were nominated in 2006 and are not included in the Boyd dataset. 
value, the more the measure indicates reference to the circuit court than to the Supreme Court. Specifically, a positive correlation between "Is Pro Owner" and either of the proportions shows a strong relationship between the use of circuit court precedent and the fact that the district court opinion was a pro-ownership opinion. For patent opinions, a positive correlation coefficient would support our hypothesis, that Federal Circuit precedent is relied on more in pro-ownership opinions in relation to Supreme Court precedent. When we compare copyright opinions to patent opinions, we report the difference as the mean value for patent opinions minus the mean value for copyright opinions. A positive difference would, therefore, indicate a correlation between the opinion being a patent opinion (rather than a copyright opinion) and more reliance on circuit precedent.

Second, we measured the weight-or emphasis_-given to cases from each court. These measures are calculated as average cites per case:

$$
\begin{gathered}
\text { Supreme Court Weight }=\frac{\text { SupremeCourtCites }}{\text { SupremeCourtCases }} \\
\text { Circuit Weight }=\frac{\text { CircuitCourtCites }}{\text { CircuitCourtCases }}
\end{gathered}
$$

The Federal Circuit is the circuit used for comparison in patent cases. For the copyright cases, the circuit that is used for comparison is the regional circuit in which the district court is located. The weight measures have a lower bound of zero, but have no upper bound. For instance, one could, theoretically, have a value of 100 for Supreme Court weight if a district court opinion cited only one Supreme Court case, but cited it 100 times. $^{32}$ For district court opinions that cited no precedent from either the Circuit Court or the Supreme Court, the respective weight was set to zero. To capture the relation between these two weights, we also calculated the quotient of these weights. Like the proportion measures, by using Circuit Weight as the numerator, larger (more positive) values indicate more emphasis on circuit court precedent. To enable us to include the district court opinions where no circuit court cases were cited, and Circuit Weight was therefore zero, we added 0.1 to both the numerator and denominator of the weight quotient. While this makes the interpretation of each weight quotient value more difficult, it should have no effect on comparing two Weight Quotients.

$$
\text { Weight Quotient }=\frac{\text { CircuitWeight }+0.1}{\text { SupremeCourtWeight }+0.1}
$$

The proportions and weights each capture a slightly different concept. The Case Proportion measure illustrates which precedent the district court relied on. This should, in theory, be the measure that the district court judge has the least control over. If a case is on point, it should likely be at least mentioned in the opinion. A judge, in fact, may cite a case, especially if it was raised by one of the parties in a brief, only to distinguish it.

\footnotetext{
${ }^{32}$ In our dataset, the largest circuit weight for a copyright opinion was 10.5 , and for a patent opinion was 6.222. The largest Supreme Court Weight for a copyright opinion was 6.625, and for a patent opinion was 4.333.
} 
The Cite Proportion and weight measures address not which precedent is used, but how it is used (that is, used with great emphasis, some emphasis, or little emphasis). How the precedent is used is something that is more within the control of the judge, and should reflect more clearly the judge's view of the case. Cite Proportion gives a general indication of how much reliance is placed on each institution. While two opinions may cite the same number of cases (and therefore have identical Case Proportions), the Cite Proportion measures may be very different, depending on how often those cases are cited. One way to think of Cite Proportion is that it captures how much the district judge ties the facts and reasoning of the case to the doctrines and reasoning of the higher court (Supreme Court and Circuit Court) precedent. The weight measures attempt to capture the concept of how much "emphasis" a district court judge puts on the opinions of each institution. ${ }^{33}$ They are different than Cite Proportion because they are more robust to variances between number of cases cited from each institution. In other words, Cite Proportion will be at least partially correlated with Case Proportion, whereas the weight measures controls for the number of cases used. This means that the weight measure for each institution has independent meaning, whereas the proportion measures are meaningful as a comparison between institutions. If, as was mentioned above, judges have limited discretion over which cases they cite, the weight measures, like the Cite Proportion measure helps capture how they use those cases.

An example may help to clarify the difference in the measures. Consider Adobe Sys. $v$. Canus Prods, ${ }^{34}$ where Judge Pregerson cited 3 cases from the Supreme Court and 2 cases from the Ninth Circuit. The Case Proportion is, therefore, 60\% (or 2/5) indicating a slight reliance on Supreme Court cases over the regional circuit. Because Judge Pregerson cited those Supreme Court cases a total of 5 times and the circuit cases 21 times, the Cite Proportion is $80.8 \%$ (or 21/26), which favors the regional circuit slightly over the mean. ${ }^{35}$ The Circuit Weight is $21 / 2$ (21 cites to 2 regional circuit cases), or 10.5 , which is the highest Circuit Weight in our sample. The Supreme Court Weight is calculated as 5/3 (five cites to three Supreme Court cases), or 1.666. The Weight Quotient was 6, higher than the mean. ${ }^{36}$ So, while it appears that there may have been more Supreme Court cases relating to the case than circuit cases, Judge Pregerson relied more on the circuit precedent in supporting the opinion.

\section{RESULTS}

\section{A. Federal Circuit More Authoritative}

If the Federal Circuit is more authoritative on patent law than the regional circuit is on copyright law, we would expect that patent opinions would rely more on Federal Circuit precedent than copyright opinions rely on regional circuit opinion.Error! Reference source not found. Table 1 compares the means of the proportion measures of citations for patent and copyright opinions. It shows that the expectation holds, and that there is more reliance on the Federal Circuit than the regional circuit in their respective contexts. This was true for both Case Proportion and Cite Proportion.

\footnotetext{
${ }^{33}$ For consistency with the other measures, we calculated this as a difference between the circuit and the Supreme Court. When appropriate, however, we also report circuit weights (not in relation to the Supreme Court weight).

34173 F. Supp. 2 d (C.D. Cal. 2001).

35 The mean of Cite Proportion in our sample is $73.7 \%$, with a standard deviation of $25.7 \%$.

36 The mean of Weight Quotient in our sample is 4.172 with a standard deviation of 7.588.
} 
For Case Proportion, the mean was $77.2 \%$ for patent opinions and $70.3 \%$ for copyright opinions. The difference of $6.8 \%$ was significant at the $5 \%$ level. This means that district court judges rely slightly more on circuit precedent (and less on Supreme Court precedent) in writing patent opinions than copyright opinions. It is a little difficult to provide a clear intuition for the difference of $6.8 \%$, but an example may help. The Case Proportion for a hypothetical opinion that cited 8 circuit cases and 2 Supreme Court cases would be $80 \% .^{37}$ This difference reported in Table 1 for Case Proportion is approximately the same as adding 1 Supreme Court case. ${ }^{38}$ Such a hypothetical is fairly in line with those found in our sample. In our sample, the copyright opinions cited a mean of 3.19 Supreme Court cases and 7.80 regional circuit cases. Patent opinions in our sample cited a mean of 2.70 Supreme Court cases and 11.97 Federal Circuit cases. District court judges therefore appear both to cite more circuit and fewer Supreme Court cases in patent opinions than in copyright opinions.

Table 1. Two Group t-test of Proportions for All Opinions

\begin{tabular}{|l|c|c|cc|}
\hline Proportions & $\begin{array}{c}\text { Patent Opinions Mean of } \\
\text { Measures }\end{array}$ & $\begin{array}{c}\text { Copyright Opinions Mean of } \\
\text { Measures }\end{array}$ & Diff \\
\hline Cir. Case Proportion & $\begin{array}{c}77.2 \% \\
(\mathrm{~N}=136)\end{array}$ & $\begin{array}{c}70.3 \% \\
(\mathrm{~N}=102)\end{array}$ & $6.8 \%$ & $*$ \\
\hline Cir. Cite Proportion & $\begin{array}{c}77.7 \% \\
(\mathrm{~N}=136)\end{array}$ & $\begin{array}{c}68.4 \% \\
(\mathrm{~N}=102)\end{array}$ & $9.4 \%$ & $* *$ \\
\hline
\end{tabular}

$* *=1 \%$ significance level, $*=5 \%$ significance level, $+=10 \%$ significance level $^{3 \%}$

For Cite Proportion, the difference in the means was $9.4 \%$ and was significant at the $1 \%$ level. The fact that this difference was larger than Case Proportion reinforces the idea that district court judges have more discretion in how they use precedent than in what precedent they select. Like Case Proportion, it appears that district court judges both have more cites to circuit cases and less to Supreme Court cases in patent opinions than in copyright opinions. ${ }^{40}$

The weight measures (and quotient) are reported in Table 2. The difference in the Circuit Weight was 0.274 , significant at the $5 \%$ level. This means that our sample reveals a difference in how much emphasis district court judges put on Federal Circuit precedent (in patent cases) compared with regional circuit precedent (in copyright cases). The difference, however, in Supreme Court Weight was -0.038 but was not statistically significant. In addition, the difference in Weight Quotient was 0.890 but was also not statistically significant. ${ }^{41}$ As discussed above, these weight measures are robust to number of cases cited from each court. The difference in emphasis placed on circuit cases cannot be attributed, therefore, to a larger number

\footnotetext{
${ }^{37} 8$ circuit cases / ( 2 Supreme Court cases +8 circuit cases $)=80 \%$

${ }^{38} 8$ circuit cases / ( 3 Supreme Court cases +8 circuit cases) $=72.7 \%$

${ }^{39}$ Cir. Case Proportion t-value $=2.2829, \mathrm{p}$-value $=0.0233$; Cir. Cite Proportion t-value $=2.8260, \mathrm{p}$-value $=0.0051$. Significance is not robust to the non-parametric Wilcoxon rank sum test. In general, the rank sum test resulted in similar or higher significance. We have noted the occasions where the rank sum test resulted in a lower level of statistical significance, and where it is especially more significant under Wilcoxon-e.g., result not statistically significant under t-test, but significant under rank sum.

${ }^{40}$ For patent opinions, the mean number of Supreme Court cites was 5.24 and mean number of circuit cites was 24.51. For copyright opinions the means were 6.25 and 13.39 respectively.

${ }^{41}$ The Weight Quotient was significant under the non-parametric Wilcoxon rank sum test at the $1 \%$ level.
} 
of patent cases from the Federal Circuit compared with copyright cases from the regional circuits. This is reinforced by the lack of a significant difference in weight on Supreme Court cases to match that found in the weight on circuit cases. If district judges were simply relying on cases from the Supreme Court that were more on-point in the copyright context, we would expect to see a shift in emphasis between the courts, whereas our sample data, at least, shows a one-sided emphasis.

Table 2. Two Group t-test of Weights for All Opinions

\begin{tabular}{|l|c|c|c|}
\hline Weights & $\begin{array}{c}\text { Patent Opinions Mean of } \\
\text { Measures }\end{array}$ & $\begin{array}{c}\text { Copyright Opinions Mean of } \\
\text { Measures }\end{array}$ & Diff \\
\hline Circuit Weight & $\begin{array}{c}1.859 \\
(\mathrm{~N}=141)\end{array}$ & $\begin{array}{c}1.585 \\
(\mathrm{~N}=109)\end{array}$ & $0.274 *$ \\
\hline SCOTUS Weight & $\begin{array}{c}1.407 \\
(\mathrm{~N}=141)\end{array}$ & $\begin{array}{c}1.445 \\
(\mathrm{~N}=109)\end{array}$ & -0.038 \\
\hline Weight Quotient & $\begin{array}{c}4.560 \\
(\mathrm{~N}=141)\end{array}$ & $(\mathrm{N}=109)$ & 0.890 \\
\hline
\end{tabular}

$* *=1 \%$ significance level, $*=5 \%$ significance level, $+=10 \%$ significance level $^{42}$

\section{B. Federal Circuit More Pro-IP}

If the Federal Circuit is more pro-ownership than the Supreme Court, we would expect that pro-patent district court opinions would have a relatively higher reliance on Federal Circuit precedent than anti-patent district court opinions. We examined whether this is the case both by looking at all precedent cited in district court opinions, as well as looking only at precedent cited in relation to intellectual property law.

\section{All Precedent}

We first compare precedent cited in pro-patent district court opinions to that cited in antipatent opinions. The results for the proportion measures are reported in Table 3. The difference of $13.4 \%$ in Case Proportion indicates that pro-patent opinions cite more Federal Circuit cases than anti-patent opinions. This was significant at the $1 \%$ level. Returning to our hypothetical opinion, which cites 2 Supreme Court cases and 8 circuit cases, a $13.4 \%$ difference is approximately the same as adding 2 Supreme Court cases. ${ }^{\mathbf{4 3}}$ The difference in Cite Proportion was $16.4 \%$, significant at the $1 \%$ level. As we saw when comparing copyright and patent opinions, the difference in Cite Proportion is larger than Case Proportion. Again, this reinforces the idea that district court judges have more discretion in how they cite than in what they cite.

\footnotetext{
${ }^{42}$ Circuit Weight $\mathrm{t}$-value $=2.0415, \mathrm{p}$-value $=0.0425 ;$ SCOTUS Weight $\mathrm{t}$-value $=-0.2701, \mathrm{p}$-value $=0.7873 ;$ Weight Quotient t-value $=0.9160$, p-value $=0.3607$.

${ }^{43} 8$ Supreme Court cases / ( 4 Supreme Court cases +8 circuit cases $)=66.6 \%$
} 
Table 3. Two Group t--test of Proportions for Patent Opinions

\begin{tabular}{|c|c|c|c|}
\hline Proportions & $\begin{array}{l}\text { Pro-Ownership Opinions } \\
\text { Mean of Measures }\end{array}$ & $\begin{array}{l}\text { Anti-Ownership Opinions } \\
\text { Mean of Measures }\end{array}$ & Diff \\
\hline Cir. Case Proportion & $\begin{array}{c}83.6 \% \\
(\mathrm{~N}=62)\end{array}$ & $\begin{array}{c}70.2 \% \\
(\mathrm{~N}=69)\end{array}$ & $13.4 \% \quad * *$ \\
\hline Cir. Cite Proportion & $\begin{array}{l}85.9 \% \\
(\mathrm{~N}=62)\end{array}$ & $\begin{array}{c}69.5 \% \\
(\mathrm{~N}=69)\end{array}$ & $16.4 \% \quad * *$ \\
\hline
\end{tabular}

$* *=1 \%$ significance level, $*=5 \%$ significance level, $+=10 \%$ significance level $^{44}$

The difference in weights between pro- and anti-patent opinions are reported in Table 4. The difference in the Weight Quotient was 2.359, which was significant at the $10 \%$ level. ${ }^{45}$ This means that more emphasis was placed on Federal Circuit cases, as compared with Supreme Court cases, in pro-patent decisions. In looking at the individual weights, it appears that between pro- and anti-patent decisions, it is the emphasis on the Supreme Court, and not the emphasis on the Federal Circuit, that is in flux. This is in contrast to what was observed in the previous section, where the variation in emphasis between copyright and patent opinions was driven by changes in emphasis to the circuit courts. Here, the difference in Supreme Court Weight was 0.098 , significant at the $1 \%$ level, but the difference in Circuit Weight was -0.533 , which was not statistically significant at all. District court judges, therefore, appear to put more emphasis on Supreme Court precedent, but not necessarily less emphasis on the Federal Circuit, in anti-patent opinions.

Table 4. Two Group t--test of Weights for Patent Opinions

\begin{tabular}{|c|c|c|c|}
\hline Weights & $\begin{array}{c}\text { Pro-Ownership Opinions } \\
\text { Mean of Measures }\end{array}$ & $\begin{array}{c}\text { Anti-Owne rship Opinions } \\
\text { Mean of Measures }\end{array}$ & Diff \\
\hline Circuit Weight & $\begin{array}{c}1.939 \\
(\mathrm{~N}=64)\end{array}$ & $\begin{array}{c}1.841 \\
(\mathrm{~N}=71)\end{array}$ & 0.098 \\
\hline SCOTUS Weight & $\begin{array}{c}1.170 \\
(\mathrm{~N}=64)\end{array}$ & $\begin{array}{c}1.703 \\
(\mathrm{~N}=71)\end{array}$ & $-0.533 * *$ \\
\hline Weight Quotient & $\begin{array}{c}5.536 \\
(\mathrm{~N}=64)\end{array}$ & $\begin{array}{c}3.176 \\
(\mathrm{~N}=71)\end{array}$ & $2.359+$ \\
\hline
\end{tabular}

$* *=1 \%$ significance level, $*=5 \%$ significance level, $+=10 \%$ significance level $^{46}$

While it appears that how the district courts rely on Federal Circuit precedent is correlated with opinion outcome, the situation is a little more muddled with copyright opinions and the regional circuits. The differences in the proportions in copyright opinions, shown in Table 5Table 5, are less than that in the patent opinions. The difference in Case Proportion between pro-ownership and anti-ownership copyright opinions is $8.0 \%$, and the difference in Cite Proportion is $8.8 \%$. Both of these were significant at the at the $10 \%$ level. ${ }^{47}$

\footnotetext{
${ }^{44}$ Cir. Case Proportion t-value $=3.5448, \mathrm{p}$-value $=0.0006$; Cir. Cite Proportion t-value $=4.0193, \mathrm{p}$-value $=0.0001$.

${ }^{45}$ The Weight Quotient was significant under the non-parametric Wilcoxon rank sum test at the $1 \%$ level.

${ }^{46}$ Circuit Weight $\mathrm{t}$-value $=0.6270, \mathrm{p}$-value $=0.5317$; SCOTUS Weight $\mathrm{t}$-value $=-3.0640, \mathrm{p}$-value $=0.0026$; Weight Quotient t-value $=1.8798, \mathrm{p}$-value $=0.0623$.

${ }^{47}$ The p-values for the non-parametric Wilcoxon rank sum test were 0.1593 for Case Proportion and 0.0929 for Cite Proportion. Case Proportion was therefore not significant under the non-parametric Wilcoxon rank sum test.
} 
In addition to the fact that the correlation between outcome and reliance on precedent seems to be lower in copyright opinions, there are two other points to note about these findings. First, there seems to be less difference in the results of the proportion measures in the copyright context than in the patent context. If we consider Cite Proportion as more discretionary than Case Proportion, it seems that district court judges might exercise this discretion less in copyright opinions than in patent opinions. Second, while the differences in the measures are lower, they go in the same direction as patent opinions. More circuit cases are cited (and cited more often) in comparison to Supreme Court cases in pro-ownership opinions than in antiownership opinions. Such a finding might indicate that the precedent from the regional circuits, like that of the Federal Circuit, is relied on more in pro-ownership opinions.

Table 5. Two Group t--test of Proportions for Copyright Opinions

\begin{tabular}{|c|c|c|c|}
\hline Measures & $\begin{array}{c}\text { Pro-Owne rship Opinions } \\
\text { Mean of Measures }\end{array}$ & $\begin{array}{c}\text { Anti-Ownership Opinions } \\
\text { Mean of Me asures }\end{array}$ & Diff \\
\hline Cir. Case Proportion & $\begin{array}{c}72.7 \% \\
(\mathrm{~N}=53)\end{array}$ & $\begin{array}{c}64.6 \% \\
(\mathrm{~N}=42)\end{array}$ & $8.0 \%$ \\
\hline Cir. Cite Proportion & $\begin{array}{c}70.8 \% \\
(\mathrm{~N}=53)\end{array}$ & $\begin{array}{c}62.0 \% \\
(\mathrm{~N}=42)\end{array}$ & $8.8 \%$ \\
\hline
\end{tabular}

$* *=1 \%$ significance level, $*=5 \%$ significance level, $+=10 \%$ significance level $^{48}$

The differences in the weights for pro- and anti-copyright opinions show that there was no statistically significant difference in how district court judges emphasized either the Supreme Court or the regional circuit when deciding a copyright opinion in favor of the owner as compared with against the owner. ${ }^{49}$ The difference in Weight Quotient, reported in Table 6, was 1.152 , but was not statistically significant. Neither of the differences in the individual weights were statistically significant.

Table 6. Two Group t-test of Weights for Copyright Opinions

\begin{tabular}{|l|c|c|c|}
\hline Weights & $\begin{array}{c}\text { Pro-Ownership Opinions } \\
\text { Mean of Measures }\end{array}$ & $\begin{array}{c}\text { Anti-Owne rship Opinions } \\
\text { Mean of Measures }\end{array}$ & Diff \\
\hline Circuit Weight & $\begin{array}{c}1.507 \\
(\mathrm{~N}=59)\end{array}$ & $\begin{array}{c}1.646 \\
(\mathrm{~N}=43)\end{array}$ & -0.139 \\
\hline SCOTUS Weight & $\begin{array}{c}1.363 \\
(\mathrm{~N}=59)\end{array}$ & $\begin{array}{c}1.671 \\
(\mathrm{~N}=43)\end{array}$ & -0.308 \\
\hline Weight Quotient & $\begin{array}{c}3.772 \\
(\mathrm{~N}=59)\end{array}$ & $\begin{array}{c}2.620 \\
(\mathrm{~N}=43)\end{array}$ & 1.152 \\
\hline
\end{tabular}

$* *=1 \%$ significance level, $*=5 \%$ significance level, $+=10 \%$ significance level $^{50}$

${ }^{48}$ Cir. Case Proportion t-value $=1.7098, \mathrm{p}$-value $=0.0906$; Cir. Cite Proportion t-value $=1.6656, \mathrm{p}$-value $=0.0992$.

49 The Supreme Court Weight was significant under the non-parametric Wilcoxon rank sum test at the $10 \%$ level, and Weight Quotient was significant at the $5 \%$ level.

${ }^{50}$ Circuit Weight t-value $=-0.5884, \mathrm{p}$-value $=0.5576$; SCOTUS Weight $\mathrm{t}$-value $=-1.3493, \mathrm{p}$-value $=0.1803$; Weight Quotient t-value $=0.7789$, p-value $=0.4379$. 
The copyright law of the regional circuits will, of course, vary. These variances will likely make certain circuits more pro-copyright and others anti-copyright. This variance may explain why it is more difficult to see a clear correlation between the measures and whether the opinion was pro-copyright or anti-copyright. We have attempted to address these circuit variances. First, we ran a regression using outcome of district court copyright opinions as the independent variable and the circuits that the districts resided in did indicate that the Ninth and Fifth Circuits might be more pro-copyright than the others, although the results were not statistically significant. When the tests reported in Table 5 and Table 6 were run removing the copyright opinions from districts in these circuits, the results were similar to the results to those reported, and none were statistically significant. In addition, the regression reported in section III.C controlled for regional circuit variances.

Since the measures appear to be more correlated to outcomes in patents than in copyright, we would expect to see a difference in the means when comparing opinions with similar outcomes between patent and copyright opinions. Table 7 and Table 8 show that, for proownership opinions, this is the case. There is more reliance on circuit opinion in patent cases than in copyright cases. Table 7 reports the proportion differences for pro-ownership copyright and patent opinions. The difference in Case Proportion measure is $11.0 \%$. As we have seen before, the Cite Proportion measure goes in the same direction, and is larger at $15.1 \%$. Both measures were significant at the $1 \%$ level. The pattern of a larger difference in Cite Proportion than Case Proportion continues.

Table 7. Two Group t-test of Proportions for Pro-Ownership Opinions

\begin{tabular}{|c|c|c|c|}
\hline Measures & $\begin{array}{c}\text { Patent Opinions Mean of } \\
\text { Measures } \\
\end{array}$ & $\begin{array}{c}\text { Copyright Opinions Mean of } \\
\text { Measures } \\
\end{array}$ & Diff \\
\hline Cir. Case Proportion & $\begin{array}{c}83.6 \% \\
(\mathrm{~N}=62) \\
\end{array}$ & $\begin{array}{c}72.7 \% \\
(\mathrm{~N}=53) \\
\end{array}$ & $11.0 \% \quad * *$ \\
\hline Cir. Cite Proportion & $\begin{array}{l}85.9 \% \\
(\mathrm{~N}=62)\end{array}$ & $\begin{array}{c}70.8 \% \\
(\mathrm{~N}=53)\end{array}$ & $15.1 \%$ \\
\hline
\end{tabular}

$* *=1 \%$ significance level, $*=5 \%$ significance level, $+=10 \%$ significance level $^{51}$

Table 8 reports the differences in weights for pro-ownership patent and copyright opinions. The Weight Quotient was 1.763, which was not statistically significant. ${ }^{52}$ Like the $^{2}$ previous results, the Weight Quotient only tells half the story, and the change in emphasis is not symmetrical between the circuit courts and the Supreme Court. The difference in Circuit Court Weight was 0.432 , significant at the $1 \%$ level. The difference in Supreme Court Weight, on the other hand, was -0.193 , which was not statistically significant. This is consistent with what was observed when comparing all opinions (both pro- and anti-ownership), where it appeared that patent opinions put more emphasis on circuit precedent, but not necessarily less on Supreme Court precedent, in patent opinions.

${ }^{51}$ Cir. Case Proportion t-value $=3.0271, \mathrm{p}$-value $=0.0031$; Cir. Cite Proportion t-value $=3.6931, \mathrm{p}$-value $=0.0004$.

${ }^{52}$ The Weight Quotient was significant under the non-parametric Wilcoxon rank sum test at the $1 \%$ level. 
Table 8. Two Group t-test of Weights for Pro-Ownership Opinions

\begin{tabular}{|l|c|c|c|}
\hline Weights & $\begin{array}{c}\text { Patent Opinions Mean of } \\
\text { Measures }\end{array}$ & $\begin{array}{c}\text { Copyright Opinions Mean of } \\
\text { Measures }\end{array}$ & Diff \\
\hline Circuit Weight & 1.939 & 1.507 & $0.432 \quad * *$ \\
$(\mathrm{~N}=64)$ & 1.363 & \\
\hline SCOTUS Weight & 1.170 & $(\mathrm{~N}=59)$ & -0.193 \\
\hline Weight Quotient & 5.536 & 3.772 & 1.763 \\
& $(\mathrm{~N}=64)$ & $(\mathrm{N}=59)$ & \\
\hline
\end{tabular}

$* *=1 \%$ significance level, $*=5 \%$ significance level, $+=10 \%$ significance level $^{53}$

We would also expect to see a correlation in the anti-ownership opinions, where antiownership patent opinions would rely less on circuit precedent and more on Supreme Court precedent than would copyright opinions. Based on our data, however, such a correlation is not as clear. The details of the comparison of anti-patent and anti-copyright opinions are listed in Table 9 and Table 10.

Table 9Table 9 reports the differences in proportions for anti-ownership opinions. The values of the differences in the Case Proportion and Cite Proportion measures were lower than in the pro-ownership opinions and none of the results of this test were statistically significant. ${ }^{54}$

Table 9. Two Group t-test of Proportions for Anti-Ownership Opinions

\begin{tabular}{|l|c|c|c|}
\hline Measures & $\begin{array}{c}\text { Patent Opinions Mean of } \\
\text { Measures }\end{array}$ & $\begin{array}{c}\text { Copyright Opinions Mean of } \\
\text { Measures }\end{array}$ & Diff \\
\hline Cir. Case Proportion & $\begin{array}{c}70.2 \% \\
(\mathrm{~N}=69)\end{array}$ & $\begin{array}{c}64.6 \% \\
(\mathrm{~N}=42)\end{array}$ & $5.6 \%$ \\
\hline \multirow{2}{*}{ Cir. Cite Proportion } & $69.5 \%$ & $62.0 \%$ & $7.5 \%$ \\
$(\mathrm{~N}=69)$ & $(\mathrm{N}=42)$ & \\
\hline
\end{tabular}

$* *=1 \%$ significance level, $*=5 \%$ significance level, $+=10 \%$ significance level $^{55}$

Table 10 reports the differences in the weights between anti-ownership copyright and patent opinions. Neither the difference in the Weight Quotient or the individual weights were statistically significant. ${ }^{56}$ There is still, however, something interesting to note: the difference in Weight Quotient was positive. This means that the relative emphasis shifted toward the Federal Circuit in anti-patent opinions. This is a somewhat unexpected result, as we might expect the shift in emphasis between anti-ownership copyright and patent opinions to go away from circuit precedent for anti-patent opinions. In other words, if the Federal Circuit precedent is proownership compared with the regional circuits, we would expect that it would be relied on less

\footnotetext{
${ }^{53}$ Circuit Weight $\mathrm{t}$-value $=3.0235$, $\mathrm{p}$-value $=0.0031 ;$ SCOTUS Weight $\mathrm{t}$-value $=-1.0024, \mathrm{p}$-value $=0.3182 ;$ Weight Quotient t-value $=1.2184$, $\mathrm{p}$-value $=0.2254$.

${ }^{54}$ The respective t-test p-values for the Case Proportion and Cite Proportion were 0.2522 and 0.1654 . For the nonparametric Wilcoxon rank sum test, they were 0.1854 and 0.0856 , respectively. Thus, under the non-parametric Wilcoxon rank sum test Cite Proportion was both significant at the $10 \%$ level.

${ }_{55}^{55}$ Cir. Case Proportion t-value $=1.1511, \mathrm{p}$-value $=0.2522 ;$ Cir. Cite Proportion t-value $=1.3966, \mathrm{p}$-value $=0.1654$.

${ }^{56}$ The Circuit Weight was significant under the non-parametric Wilcoxon rank sum test at the $5 \%$ level, and the Weight Quotient was significant under the rank sum test at the $10 \%$ level.
} 
for anti-ownership opinions. It is possible, however, that the authoritative effect of the Federal Circuit that was observed previously is only mitigated, and not completely cancelled out, by the pro-ownership effect. The interaction of the authoritative effect and the pro-ownership effect is investigated further in Part III.C.

Table 10. Two Group t-test of Weights for Anti-Ownership Opinions

\begin{tabular}{|l|c|c|c|}
\hline Weights & $\begin{array}{c}\text { Patent Opinions Mean of } \\
\text { Measures }\end{array}$ & $\begin{array}{c}\text { Copyright Opinions Mean of } \\
\text { Measures }\end{array}$ & Diff \\
\hline Circuit Weight & $\begin{array}{c}1.841 \\
(\mathrm{~N}=71)\end{array}$ & $\begin{array}{c}1.646 \\
(\mathrm{~N}=43)\end{array}$ & 0.195 \\
\hline SCOTUS Weight & 1.703 & 1.671 & 0.032 \\
$(\mathrm{~N}=71)$ & 2.620 & 0.556 \\
\hline Weight Quotient & 3.176 & $(\mathrm{~N}=43)$ & \\
\hline
\end{tabular}

$* *=1 \%$ significance level, $*=5 \%$ significance level, $+=10 \%$ significance level $^{57}$

The lack of statistically significant correlation in anti-ownership opinions requires at least a little consideration. One possible explanation is that this correlation is not as readily observable because the pro-patent effect of Federal Circuit precedent, and how it is relied on by district court judges, is stronger in pro-patent cases than in anti-patent cases. When considering this, it is important to remember that the proportions evaluate reliance on circuit precedent compared to Supreme Court precedent. This interpretation would mean that it is possible that while district court judges rely on Federal Circuit precedent in pro-patent opinions more than in anti-patent opinions, they do not necessarily rely on Supreme Court opinions more in anti-patent opinions (at least compared with what they do in copyright opinions). In other words, judges may be using their discretion in how they use precedent to make more of a point in pro-patent opinions. This would explain the lower differences in the Case Proportion and Cite Proportion measures in anti-ownership than pro-ownership opinions.

\section{IP Precedent}

There are two reasons to consider all precedent, and not just that related to intellectual property, cited in district court opinions, even when looking at whether the Federal Circuit is pro-ownership or not. First, it allows for a larger and more consistent sample set. Determining what precedent is related to intellectual property and which is not is a difficult task, requiring more human involvement, and with it possible human error. In addition, as will be discussed below, to separate out the intellectual property precedent in a somewhat automated fashion required elimination of some district court opinions from our dataset. The second reason that there is value to considering all cited precedent is that what we are measuring is how district court judges view and use the precedent of the Federal Circuit. Such use may or may not be completely limited or compartmentalized to precedent that is clearly related to intellectual property law.

\footnotetext{
${ }^{57}$ Circuit Weight $\mathrm{t}$-value $=0.8113$, $\mathrm{p}$-value $=0.4189 ;$ SCOTUS Weight $\mathrm{t}$-value $=0.1533$, $\mathrm{p}$-value $=0.8784 ;$ Weight Quotient t-value $=0.4432$, $\mathrm{p}$-value $=0.6585$.
} 
Considering all cited precedent does, however, have its drawbacks. There can be a fair amount of noise introduced by considering precedent that is not related to intellectual property. This noise is larger with copyright opinions, where we observed a larger number of issues being discussed unrelated to copyright than we saw in the patent context. ${ }^{58}$ We therefore attempted to narrow our focus to citations related to intellectual property law. We did this by doing a hand count of citations in sections of opinions that fell within Lexis headnotes related to the intellectual property discipline (patent or copyright) that the case fell in. Because Lexis did not have headnotes for every case, this meant that our sample size is lower for the following tests.

Although we are narrowing the citations to intellectual property cases, the expectations do not change from above. For patent opinions, we expect more reliance on the Federal Circuit in pro-patent district court opinions than in anti-patent opinions. The results of this comparison are detailed in Table 11 and Table 12. Table 11 reports the differences in proportions for proand anti-ownership patent opinions. The results verify what we found in

Table 3, that there is more reliance on the Federal Circuit in pro-patent opinions than in antipatent opinions. The difference in Case Proportion was $7.8 \%$, significant at the $5 \%$ level. ${ }^{59}$ The difference in Cite Proportion was $12.6 \%$, significant at the $1 \%$ level. Confirming what was seen in previous tables, the difference in Cite Proportion is larger than the difference in Case Proportion, continuing to indicate that judges may use more discretion in how they use precedent than in what precedent they use.

Table 11. Two Group t-test of Proportions for Patent Opinions, Narrowing to IP Citations

\begin{tabular}{|l|c|c|c|}
\hline Proportions & $\begin{array}{c}\text { Pro-Owne rship Opinions } \\
\text { Mean of Measures }\end{array}$ & $\begin{array}{c}\text { Anti-Owne rship Opinions } \\
\text { Mean of Me asures }\end{array}$ & Diff \\
\hline Cir. Case Proportion & $90.1 \%$ & $82.3 \%$ & $7.8 \% *$ \\
& $(\mathrm{~N}=46)$ & $79.6 \%$ & $12.6 \% * *$ \\
\hline Cir. Cite Proportion & $92.1 \%$ & $(\mathrm{~N}=56)$ & \\
\hline
\end{tabular}

$* *=1 \%$ significance level, $*=5 \%$ significance level, $+=10 \%$ significance level $^{60}$

The differences in weights for intellectual property citations in pro- and anti-ownership patent opinions are reported in Table 12. The difference in Weight Quotient was 1.393, not statistically significant. ${ }^{61}$ The difference in Circuit Weight reported here was -0.007 , also not statistically significant. The Supreme Court Weight difference, however, was -0.906 , significant at the $1 \%$ level. ${ }^{62}$ Therefore, like what was reported in Table 4, there seems to be significantly less emphasis on Supreme Court precedent in pro-patent opinions compared with anti-patent

\footnotetext{
${ }^{58}$ The mean of all circuit and Supreme Court cases cited was 14.674 for patent opinions and 10.991 for copyright opinions. When we limited to only intellectual property cases cited by headnote (as discussed infra0, the mean of the combined circuit and Supreme Court cases was 13.315 for patent opinions and 5.924 for copyright opinions. There was, therefore, an average of 1.359 non-patent cases cited in each patent opinion, compared with an average of 5.067 non-copyright cases cited in copyright opinions.

${ }^{59}$ The p-value for the non-parametric Wilcoxon rank sum test was 0.081 , making it significant at the $10 \%$ level.

${ }^{60}$ Cir. Case Proportion t-value $=2.4051, \mathrm{p}$-value $=0.0184$; Cir. Cite Proportion t-value $=3.6726, \mathrm{p}$-value $=0.0005$.

${ }^{61}$ The Weight Quotient was significant under the non-parametric Wilcoxon rank sum test at the $5 \%$ level.

${ }^{62}$ The Supreme Court Weight was significant under the non-parametric Wilcoxon rank sum test at the 5\% level.
} 
opinions, but no statistically significant change in the emphasis on Federal Circuit precedent. While the difference in Circuit Weight was not statistically significant when considering all precedent or intellectual property precedent, it should be noted that the direction of the difference flipped from positive for all precedent, to negative when narrowed to intellectual property precedent. For all precedent, therefore, we observed slightly more emphasis on Federal Circuit precedent for anti-ownership patent opinions, while for intellectual property precedent we observed slightly less emphasis on Federal Circuit precedent for anti-ownership patent opinions. The result found for all precedent is more in line with our expectations. If the Federal Circuit is a pro-ownership court, we would expect less emphasis on Federal Circuit precedent in antiownership patent opinions. The result reported in Table 12 would indicate that, in our sample, there is slightly more emphasis placed on Federal Circuit intellectual property precedent in antiownership patent opinions. One possible explanation for this would be that there is simply more emphasis placed on all intellectual property precedent when ruling against the patent owner. In other words, the district court judge does more to justify anti-ownership decisions by more reference to precedent. ${ }^{63}$

Table 12. Two Group t-test of Weights for Patent Opinions, Narrowing to IP Citations

\begin{tabular}{|l|c|c|c|}
\hline Weights & $\begin{array}{c}\text { Pro-Ownership Opinions } \\
\text { Mean of Measures }\end{array}$ & $\begin{array}{c}\text { Anti-Owne rship Opinions } \\
\text { Mean of Meas ures }\end{array}$ & Diff \\
\hline Circuit Weight & $\begin{array}{c}1.668 \\
(\mathrm{~N}=48)\end{array}$ & $\begin{array}{c}1.676 \\
(\mathrm{~N}=57)\end{array}$ & -0.007 \\
\hline SCOTUS Weight & 0.941 & 1.847 & $-0.906 * *$ \\
& $(\mathrm{~N}=48)$ & $(\mathrm{N}=57)$ & \\
\hline Weight Quotient & 5.879 & $\begin{array}{c}4.486 \\
(\mathrm{~N}=57)\end{array}$ & 1.393 \\
\hline
\end{tabular}

$* *=1 \%$ significance level, $*=5 \%$ significance level, $+=10 \%$ significance level $^{64}$

As we did with all precedent in Table 5 and

Table 6, we want to see whether this effect of more reliance on Supreme Court precedent in antiownership patent opinions holds true in the copyright context. Our expectation is that case outcome (i.e., whether the property right owner wins or loses) will not be as strongly correlated with reliance on precedent in the copyright context, which is the result we found in Table 5 and Table 6. The results of this comparison, narrowing to intellectual property precedent, are reported in Table 13 and Table 14. Table 13 reports the differences in proportions between proand anti-ownership copyright opinions. The results of Table 13 conflict with our expectations.

\footnotetext{
${ }^{63}$ To test this possibility, we ran t-tests comparing total precedent weight ((Supreme Court cites + circuit cites) / (Supreme Court cases + circuit cases). We compared both all precedent weights and intellectual property precedent weights for both all opinions and patent opinions. While none of the results were statistically significant, they all showed more emphasis overall in anti-ownership opinions than in pro-ownership opinions. For copyright opinions, the opposite was true (more emphasis overall in pro-ownership opinions), but again was not statistically significant.

${ }^{64}$ Circuit Weight t-value $=-0.0512$, p-value =0.9593; SCOTUS Weight $\mathrm{t}$-value $=-2.9131, \mathrm{p}$-value $=0.0047$; Weight Quotient t-value $=0.9708, \mathrm{p}$-value $=0.3342$.
} 
For the copyright context, while it seems that there is a less clear correlation between outcome and reliance on precedent in general, ${ }^{65}$ it appears that there may be a correlation between case outcome and reliance on intellectual property precedent. The effect is significant at the 5\% level, ${ }^{66}$ but goes in the direction opposite that in the patent context. In other words, proownership copyright opinions tend to rely on less circuit precedent (and more Supreme Court precedent) than anti-ownership copyright opinions. This is the opposite of what we have seen in the patent context, where Federal Circuit is relied on more in pro-patent opinions. It is interesting to note, however, that there is less difference in size (as opposed to direction) between the more restrictive Case Proportion measure and Cite Proportion in the copyright context than in the patent context. In the copyright context, the Cite Proportion measure was 1.24 times the corresponding Case Proportion measure $(-18.1 \% /-14.6 \%)$. In the patent context, the Cite Proportion measure was 1.61 times the corresponding Case Proportion measure (12.6\% / 7.8\%). This might indicate an institutional bias towards the Federal Circuit. In other words, the regional circuits might provide more anti-copyright opinions that the district court has limited discretion over whether to include. When it comes to how the judges use those cases, however, it appears that they tend to cite them less in anti-copyright opinions than similar emphasis on Federal Circuit cases in pro-patent opinions.

Table 13. Two Group t-test of Proportions for Copyright Opinions, Narrowing to IP Citations

\begin{tabular}{|l|c|c|c|}
\hline Proportions & $\begin{array}{c}\text { Pro-Owne rship Opinions } \\
\text { Mean of Measures }\end{array}$ & $\begin{array}{c}\text { Anti-Ownership Opinions } \\
\text { Mean of Me asures }\end{array}$ & Diff \\
\hline \multirow{2}{*}{ Cir. Case Proportion } & $69.5 \%$ & $84.2 \%$ & $-14.6 \% *$ \\
& $(\mathrm{~N}=32)$ & $(\mathrm{N}=24)$ & \\
\hline \multirow{2}{*}{ Cir. Cite Proportion } & $64.2 \%$ & $82.4 \%$ & $-18.1 \% *$ \\
& $(\mathrm{~N}=32)$ & $(\mathrm{N}=24)$ & \\
\hline
\end{tabular}

$* *=1 \%$ significance level, $*=5 \%$ significance level, $+=10 \%$ significance level $^{67}$

Table 14 reports the weight differences between pro- and anti-ownership copyright opinions. While neither of the individual weight measures were statistically significant, the weight quotient was -4.886 , significant at the 5\% level. This indicates that district courts put more emphasis on Supreme Court precedent compared with circuit precedent in pro-copyright opinions. This is consistent with the Case and Cite Proportion measures for IP precedent reported in Table 13 and may indicate that the Supreme Court precedent regarding copyright is, in general, more protective of ownership rights than regional circuit precedent.

\footnotetext{
${ }^{65}$ See Table 5, supra.

${ }^{66}$ The p-value for the non-parametric Wilcoxon rank sum test for Case Proportion was 0.0583, making it significant at the $10 \%$ level under that test.

${ }^{67}$ Cir. Case Proportion t-value $=-2.3701, \mathrm{p}$-value $=0.0214 ;$ Cir. Cite Proportion t-value $=-2.4772, \mathrm{p}$-value $=$ 0.0164 .
} 
Table 14. Two Group t-test of Weights for Copyright Opinions, Narrowing to IP Citations

\begin{tabular}{|l|c|c|c|}
\hline Weights & $\begin{array}{c}\text { Pro-Ownership Opinions } \\
\text { Mean of Measures }\end{array}$ & $\begin{array}{c}\text { Anti-Owne rship Opinions } \\
\text { Mean of Measures }\end{array}$ & Diff \\
\hline Circuit Weight & $\begin{array}{c}1.241 \\
(\mathrm{~N}=38)\end{array}$ & $\begin{array}{c}1.655 \\
(\mathrm{~N}=24)\end{array}$ & -0.414 \\
\hline SCOTUS Weight & $\begin{array}{c}1.609 \\
(\mathrm{~N}=38)\end{array}$ & $\begin{array}{c}0.938 \\
(\mathrm{~N}=24)\end{array}$ & 0.671 \\
\hline Weight Quotient & 3.450 & $\begin{array}{c}8.336 \\
(\mathrm{~N}=24)\end{array}$ & $-4.886^{*}$ \\
\hline
\end{tabular}

$* *=1 \%$ significance level, $*=5 \%$ significance level, $+=10 \%$ significance level $^{68}$

\section{How are the effects and measures related?}

The results from the previous sections tend to indicate that the Federal Circuit is more authoritative than the regional circuits in their respective intellectual property realms, and that the Federal Circuit is relied on more in pro-ownership opinions. The next question is to see how these effects and measures are related. In looking at the effects, we hope to discover whether district court judges tend to cite the Federal Circuit more because it is more authoritative or because it is more pro-ownership. In looking at measures, we want to know whether these effects play out in which cases district court judges cite, or how they cite them. To evaluate this, we ran regressions with the proportion and weight measures as the dependent variable. For the independent variables, we included whether the outcome was pro-owner or not and whether the decision was a patent decision or not. Because copyright precedent comes from the regional circuit, and patent precedent comes from the Federal Circuit, the "is patent" variable is used as a proxy for the authoritativeness of the Federal Circuit compared with the regional circuits. In addition, we included "is pro-patent" as an independent variable. This variable captures the interaction between patent opinions and pro-ownership opinions. This should allow us to capture the effect, if any, that goes beyond the simple authoritativeness of the Federal Circuit (captured by the "patent" variable) while factoring out any general pro- or anti-ownership tendencies general to both patent and copyright opinions (captured by the "is pro-owner" variable). Variables for judge, year, ideology, opinion type, and which circuit the district court sits in were also included as controls.

The results of the proportion regressions for intellectual property citations are reported in Table 15. ${ }^{69}$ The regressions show that, even with the other independent variables included, both Case Proportion and Cite Proportion are significant at the $1 \%$ level for "is pro-owner." The negative coefficient means that, when factoring out the other independent variables, pro-owner opinions rely more on Supreme Court precedent than in anti-owner opinions. This is not an unexpected result. Because "is patent" and "is pro-patent" are included as independent variables, "is pro-owner" represents moving from an anti-owner to a pro-owner opinion, controlling for any Federal Circuit effect. Therefore, this indicates a possible anti-ownership effect from the

\footnotetext{
${ }^{68}$ Circuit Weight $\mathrm{t}$-value $=-1.3107, \mathrm{p}$-value $=0.1995 ;$ SCOTUS Weight $\mathrm{t}$-value $=1.6034, \mathrm{p}$-value $=0.1141 ;$ Weight Quotient t-value $=-2.5285$, $\mathrm{p}$-value $=0.0158$.

${ }^{69}$ Regressions considering all citations were run, but not reported here. They confirmed the authoritativeness of the Federal Circuit found in the previously reported t-tests, with the "is patent" variable being statistically significant at the 10\% level for Case Proportion, at the 5\% level for Cite Proportion, and at the 1\% level for Weight Quotient.
} 
regional circuits-i.e., as we move from anti-copyright to pro-copyright opinions, regional circuit precedent is relied on less, relative to Supreme Court precedent. This result is consistent with what was reported in Table 13. The regressions also show that the coefficient for the "is pro-patent" interaction variable is statistically significant at the $1 \%$ level. The coefficient for "is pro-patent" was 0.2580 for Case Proportion and 0.3252 for Cite Proportion. These coefficients are both positive, as we would expect. This indicates that district courts rely on Federal Circuit in pro-owner decisions to a significant degree, over and above any reliance due to any effect from the Federal Circuit being more authoritative than the regional circuits.

It appears, as we have seen before, that judges are more constrained about what cases they cite than how they use those cases. This can be seen from the larger coefficients for Cite Proportion than Case Proportion for both "is pro-owner" and "is pro-patent." This difference is largest for the "is pro-patent" interaction variable.

Table 15. Linear Regression with Proportions as Dependent Variable, Narrowed to IP Precedent

\begin{tabular}{|c|c|c|}
\hline Proportions & Cir. Case Proportion & Cir. Cite Proportion \\
\hline Is Patent? & $\begin{array}{r}0.0070 \\
(0.0533) \\
\end{array}$ & $\begin{array}{r}0.0226 \\
(0.0653) \\
\end{array}$ \\
\hline Is Pro-Owner? & $\begin{array}{c}-0.1906 \\
(0.0652) * *\end{array}$ & $\begin{array}{c}-0.2198 \\
(0.0803) * *\end{array}$ \\
\hline Is Pro-Patent? & $\begin{array}{c}0.2580 \\
(0.0809) * *\end{array}$ & $\begin{array}{c}0.3252 \\
(0.0937) * *\end{array}$ \\
\hline Judge & $\begin{array}{r}0.0001 \\
(0.0004)\end{array}$ & $\begin{array}{r}0.0002 \\
(0.0005)\end{array}$ \\
\hline Ideology & $\begin{array}{r}-0.0180 \\
(0.0313) \\
\end{array}$ & $\begin{array}{r}-0.0177 \\
(0.0392) \\
\end{array}$ \\
\hline Additional Controls & $\begin{array}{l}\text { Year, Circuit, } \\
\text { Opinion Type }\end{array}$ & $\begin{array}{l}\text { Year, Circuit, } \\
\text { Opinion Type }\end{array}$ \\
\hline Standard Errors & Robust & Robust \\
\hline Sample Size & 149 & 149 \\
\hline R-Squared & 0.3425 & 0.3562 \\
\hline
\end{tabular}

The regressions for the weight measures are reported in Table 16. The results are consistent with what was reported in Table 12. When going from an anti-patent decision to a pro-patent decision, there is a statistically significant drop in emphasis on Supreme Court precedent, but not a statistically significant rise in emphasis on Federal Circuit precedent. While not statistically significant, the coefficient for "is pro-patent" does, however, go in the expected direction, while the corresponding value in Table 12 was very slightly negative. Also unlike Table 12, the Weight Quotient reported here for "is pro-patent" is statistically significant at the $5 \%$ level. This means that while there is no statistically significant absolute rise in emphasis on Federal Circuit precedent when going from anti-patent to pro-patent decisions, there is a 
statistically significant comparative rise in emphasis on Federal Circuit precedent in relation to Supreme Court precedent.

Table 16. Linear Regression with Weight Measures as Dependent Variable, Narrowed to IP Precedent

\begin{tabular}{|l|c|c|c|}
\hline \multicolumn{1}{|c|}{ Weights } & Circuit Weight & SCOTUS Weight & Weight Quotient \\
\hline Is Patent? & $\begin{array}{c}-0.0321 \\
(0.3918)\end{array}$ & $\begin{array}{c}0.3424 \\
(0.4394)\end{array}$ & $\begin{array}{c}-2.0490 \\
(1.9192)\end{array}$ \\
\hline Is Pro-Owner? & -0.5182 & 0.4843 & -5.3288 \\
& $(0.4084)$ & $(0.5371)$ & $(2.1574) *$ \\
\hline Is Pro-Patent? & 0.3978 & -1.3026 & 6.0260 \\
& $(0.4415)$ & $(0.6299) *$ & $(2.5213) *$ \\
\hline Judge & 0.0006 & 0.0039 & -0.0087 \\
& $(0.0021)$ & $(0.0045)$ & $(0.0165)$ \\
\hline Ideology & -0.0936 & -0.2412 & 1.1862 \\
& $(0.1494)$ & $(0.3353)$ & $(1.2295)$ \\
\hline Additional Controls & Year, Circuit, & Year, Circuit, & Year, Circuit, \\
& Opinion Type & Opinion Type & Opinion Type \\
\hline Standard Errors & Robust & Robust & Robust \\
\hline Sample Size & \multicolumn{1}{|c|}{158} & 158 & 158 \\
\hline R-Squared & 0.1662 & 0.2058 & 0.2673 \\
\hline \multicolumn{2}{|c|}{$* \mathbf{1 \%}$ significance level, * 5\% significance level, + 10\% significance level } \\
\end{tabular}

\section{CONCLUSION}

An empirical study of how precedent is relied on by district courts in intellectual property cases shows that two commonly held beliefs appear to be valid. First, the Federal Circuit is treated as more authoritative on patent law than the regional circuits are on copyright law. Second, the Federal Circuit's precedent tends to be relied on more in pro-patent opinions than in anti-patent opinions.

This study uncovered some further details about how these effects are played out at the district court level. First, both of these effects are seen more strongly in how the district courts use the precedent than in what precedent is used. Second, it appears that district court judges do not necessarily put more emphasis on Federal Circuit precedent in pro-ownership patent opinions, but instead put less emphasis on Supreme Court precedent in those opinions. Third, the pro-ownership effect in patent cases may be more limited to pro-ownership opinions, and less obvious in anti-ownership opinions. All three of these effects provide opportunities for further study. 


\section{APPENDIX $^{70}$}

\section{Linear Regression with Cir. Case Proportion as Dependent Variable (Table 15, Column 1)}

\begin{tabular}{|c|c|c|c|c|c|c|c|}
\hline Linear regres & & & & & & $\begin{array}{l}\text { Number of obs } \\
\text { F( 23, 125) } \\
\text { Prob > F } \\
\text { R-squared } \\
\text { Root MSE }\end{array}$ & $\begin{array}{rr}= & 149 \\
= & 4.98 \\
= & 0.0000 \\
= & 0.3425 \\
= & .19002\end{array}$ \\
\hline hn_c se_prop & 1 & Coef. & $\begin{array}{l}\text { Robust } \\
\text { Std. Err. }\end{array}$ & t & $P>|t|$ & [95\% Conf. & Interval] \\
\hline is_patent & | & .006983 & .0532792 & 0.13 & 0.896 & -.0984632 & .1124291 \\
\hline is_pro_owner & 1 & -.1905846 & .0652422 & -2.92 & 0.004 & -.3197069 & -.0614623 \\
\hline pro_patent & | & .2580048 & .0808935 & 3.19 & 0.002 & .0979066 & .418103 \\
\hline judge & | & .0001426 & .0004216 & 0.34 & 0.736 & -.0006918 & .000977 \\
\hline boyd_ideol y & | & -.0179949 & .031343 & -0.57 & 0.567 & -.0800265 & .0440367 \\
\hline is_second & i & .0243342 & .0982268 & 0.25 & 0.805 & -.1700688 & .2187372 \\
\hline is_third & i & .0352641 & .0781225 & 0.45 & 0.652 & -.1193501 & .1898784 \\
\hline is_seventh & | & .1430503 & .0810439 & 1.77 & 0.080 & -.0173457 & .3034462 \\
\hline is_ninth & | & .0656895 & .0758662 & 0.87 & 0.388 & -.0844593 & .2158382 \\
\hline is_2000 & | & -.1418731 & .0940367 & -1.51 & 0.134 & -.3279833 & .0442372 \\
\hline is_2001 & | & -.159572 & .0896434 & -1.78 & 0.077 & -.3369874 & .0178434 \\
\hline is_2002 & i & -.1760406 & .0810157 & -2.17 & 0.032 & -.3363807 & -.0157005 \\
\hline is_2003 & 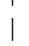 & -.031616 & .0711285 & -0.44 & 0.657 & -.1723882 & .1091561 \\
\hline is_2004 & | & -.0039945 & .0742065 & -0.05 & 0.957 & -.1508583 & .1428693 \\
\hline is_2005 & | & .0008919 & .0760052 & 0.01 & 0.991 & -.1495317 & .1513156 \\
\hline is_2006 & | & -.0627453 & .0748674 & -0.84 & 0.404 & -.2109171 & .0854265 \\
\hline opinion_t _1 & | & .0483383 & .06653 & 0.73 & 0.469 & -.0833328 & .1800095 \\
\hline opinion_t -2 & | & -.0203572 & .0439863 & -0.46 & 0.644 & -.1074114 & .0666971 \\
\hline opinion_t _3 & | & .1339394 & .0931359 & 1.44 & 0.153 & -.0503882 & .3182669 \\
\hline opinion_t $\sim 4$ & | & -.0475255 & .0644749 & -0.74 & 0.462 & -.1751295 & .0800784 \\
\hline opinion_ty 5 & | & .0457948 & .0448011 & 1.02 & 0.309 & -.0428721 & .1344617 \\
\hline opinion_ty $\sim 8$ & i & .0874268 & .1005539 & 0.87 & 0.386 & -.1115819 & .2864355 \\
\hline opinion_ty 9 & | & -.2174575 & .0750088 & -2.90 & 0.004 & -.3659092 & -.0690058 \\
\hline _cons & | & .8610256 & .107528 & 8.01 & 0.000 & .6482144 & 1.073837 \\
\hline
\end{tabular}

\section{Linear Regression with Cir. Cite Proportion as Dependent Variable (Table 15, Column 2)}

Linear regression

$\begin{array}{llr}\text { Number of obs } & = & 149 \\ \text { F }(23, \quad 125) & =3.55 \\ \text { Prob }>\text { F } & =0.0000 \\ \text { R-squared } & =0.3562 \\ \text { Root MSE } & =.21747\end{array}$

\begin{tabular}{|c|c|c|c|c|c|c|}
\hline & & Robust & & & & \\
\hline hn_c te_prop & Coef. & Std. Err. & t & $P>|t|$ & [95\% Conf. & Interval] \\
\hline is_patent & .0225773 & .0653082 & 0.35 & 0.730 & -.1066758 & .1518303 \\
\hline is_pro_owner & -.2198116 & .0803359 & -2.74 & 0.007 & -.3788062 & -.0608169 \\
\hline pro_patent & .3252329 & .0937209 & 3.47 & 0.001 & .1397476 & .5107182 \\
\hline judge & .0001512 & .0004985 & 0.30 & 0.762 & -.0008353 & .0011377 \\
\hline boyd_ideol y & -.0176568 & .0391937 & -0.45 & 0.653 & -.0952259 & .0599124 \\
\hline
\end{tabular}

${ }^{70}$ All data, code, and results are on file with authors. 


\begin{tabular}{|c|c|c|c|c|c|c|c|}
\hline is_second & I & .0130419 & .1040292 & 0.13 & 0.900 & -.1928447 & .2189285 \\
\hline is_third & i & .023445 & .0806713 & 0.29 & 0.772 & -.1362135 & .1831034 \\
\hline is_seventh & | & .143922 & .0848165 & 1.70 & 0.092 & -.0239404 & .3117844 \\
\hline is_ninth & | & .0396649 & .082685 & 0.48 & 0.632 & -.123979 & .2033087 \\
\hline is_z2000 & i & -.1201997 & .1189648 & -1.01 & 0.314 & -.3556458 & .1152464 \\
\hline is_2001 & | & -.1013883 & .115368 & -0.88 & 0.381 & -.329716 & .1269393 \\
\hline is_2002 & i & -.1828865 & .1095922 & -1.67 & 0.098 & -.399783 & .03401 \\
\hline is_2003 & i & -.0083137 & .1026952 & -0.08 & 0.936 & -.2115601 & .1949328 \\
\hline is_2004 & | & -.0244047 & .1192376 & -0.20 & 0.838 & -.2603907 & .2115812 \\
\hline is_2005 & | & .0264315 & .1042955 & 0.25 & 0.800 & -.1799823 & .2328454 \\
\hline is_2006 & i & -.0460059 & .1109605 & -0.41 & 0.679 & -.2656104 & .1735986 \\
\hline opinion_t _1 & | & .0439879 & .0748685 & 0.59 & 0.558 & -.1041862 & .192162 \\
\hline opinion_t ${ }^{2}$ & | & -.0398235 & .05923 & -0.67 & 0.503 & -.157047 & .0774 \\
\hline opinion_t _-3 & i & .1781669 & .1024704 & 1.74 & 0.085 & -.0246347 & .3809686 \\
\hline opinion_t ${ }^{4}$ & I & -.076124 & .0796211 & -0.96 & 0.341 & -.233704 & .0814559 \\
\hline opinion_ty 5 & | & -.0211776 & .0664159 & -0.32 & 0.750 & -.152623 & .110267 \\
\hline opinion_ty $\sim 8$ & i & .0568823 & .1185299 & 0.48 & 0.632 & -.1777031 & .2914678 \\
\hline opinion_ty 9 & 1 & -.2581064 & .1275357 & -2.02 & 0.045 & -.5105155 & -.0056974 \\
\hline _cons & | & .8443021 & .1390737 & 6.07 & 0.000 & .5690581 & 1.119546 \\
\hline
\end{tabular}

Linear Regression with Circuit Weight as Dependent Variable (Table 16, Column 1)

Linear regression

$\begin{array}{llr}\text { Number of obs } & = & 158 \\ \text { F (23, 134) } & =1.75 \\ \text { Prob }>\text { F } & =0.0268 \\ \text { R-squared } & =0.1662 \\ \text { Root MSE } & =.90069\end{array}$

\begin{tabular}{|c|c|c|c|c|c|c|c|}
\hline hn_circuit t & 1 & Coef. & $\begin{array}{l}\text { Robust } \\
\text { Std. Err. }\end{array}$ & t & $P>|t|$ & [95\% Conf. & Interval] \\
\hline is_patent & | & -.0320531 & .3917833 & -0.08 & 0.935 & -.8069322 & .7428259 \\
\hline is_pro_owner & 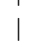 & -.5181547 & .4084069 & -1.27 & 0.207 & -1.325912 & .2896031 \\
\hline pro_patent & i & .3978305 & .4414539 & 0.90 & 0.369 & -.4752885 & 1.270949 \\
\hline judge & | & .0006326 & .0021223 & 0.30 & 0.766 & -.0035649 & .0048302 \\
\hline boyd_ideol $\sim y$ & | & -.0935779 & .1493525 & -0.63 & 0.532 & -.3889711 & .2018153 \\
\hline is_second & | & -.2189401 & .317504 & -0.69 & 0.492 & -.8469076 & .4090275 \\
\hline is_third & । & .0121411 & .2228146 & 0.05 & 0.957 & -.4285474 & .4528296 \\
\hline is_seventh & | & -.0867455 & .2439071 & -0.36 & 0.723 & -.5691513 & .3956603 \\
\hline is_ninth & 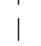 & .3143262 & .2296458 & 1.37 & 0.173 & -.1398733 & .7685256 \\
\hline is_2000 & 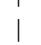 & .1831585 & .238057 & 0.77 & 0.443 & -.2876767 & .6539937 \\
\hline is_2001 & | & .5287747 & .3582493 & 1.48 & 0.142 & -.17978 & 1.237329 \\
\hline is_2002 & 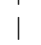 & .0869714 & .216996 & 0.40 & 0.689 & -.3422088 & .5161516 \\
\hline is_2003 & । & .3499274 & .2170085 & 1.61 & 0.109 & -.0792777 & .7791324 \\
\hline is_2004 & | & .3843854 & .3152086 & 1.22 & 0.225 & -.2390422 & 1.007813 \\
\hline is_2005 & 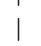 & .1906946 & .2856031 & 0.67 & 0.505 & -.3741786 & .7555679 \\
\hline is_2006 & 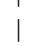 & .3538839 & .3088964 & 1.15 & 0.254 & -.2570594 & .9648272 \\
\hline opinion_t _1 & | & .2824483 & .4618257 & 0.61 & 0.542 & -.6309625 & 1.195859 \\
\hline opinion_t _2 & 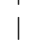 & -.118533 & .4579474 & -0.26 & 0.796 & -1.024273 & .7872071 \\
\hline opinion_t _-3 & i & -.4945784 & .5369271 & -0.92 & 0.359 & -1.556527 & .5673697 \\
\hline opinion_t _4 & | & -.3059332 & .4703627 & -0.65 & 0.517 & -1.236229 & .6243622 \\
\hline opinion_ty $\sim 5$ & 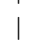 & -.1231056 & .4609191 & -0.27 & 0.790 & -1.034723 & .788512 \\
\hline opinion_ty 8 & 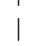 & .1254773 & .5089038 & 0.25 & 0.806 & -.8810458 & 1.132 \\
\hline opinion_ty $\sim 9$ & । & -.6286635 & .6514505 & -0.97 & 0.336 & -1.917119 & .6597921 \\
\hline _cons & | & 1.509419 & .6057815 & 2.49 & 0.014 & .3112889 & 2.70755 \\
\hline
\end{tabular}

\section{Linear Regression with SCOTUS Weight as Dependent Variable (Table 16, Column 2)}




$\begin{array}{llr}\mathrm{F}(23,134) & =1.70 \\ \text { Prob }>\mathrm{F} & =0.0336 \\ \text { R-squared } & =0.2058 \\ \text { Root MSE } & =1.7147\end{array}$

\begin{tabular}{|c|c|c|c|c|c|c|c|}
\hline hn_scotus_ $t$ & 1 & Coef. & $\begin{array}{l}\text { Robust } \\
\text { Std. Err. }\end{array}$ & t & $P>|t|$ & [95\% Conf. & Interval ] \\
\hline is_patent & | & .3424121 & .4394216 & 0.78 & 0.437 & -.5266871 & 1.211511 \\
\hline is_pro_owner & । & .4842537 & .5371334 & 0.90 & 0.369 & -.5781025 & 1.54661 \\
\hline pro_patent & | & -1.302605 & .6298732 & -2.07 & 0.041 & -2.548385 & -.0568257 \\
\hline judge & | & .0038595 & .0044596 & 0.87 & 0.388 & -.0049609 & .0126799 \\
\hline boyd_ideol $\sim y$ & | & -.2412397 & .3352923 & -0.72 & 0.473 & -.9043894 & .4219101 \\
\hline is_second & | & -.3601966 & .3882825 & -0.93 & 0.355 & -1.128152 & .4077584 \\
\hline is_third & | & .2315396 & .3705117 & 0.62 & 0.533 & -.501268 & .9643472 \\
\hline is_seventh & । & -.4913369 & .4145224 & -1.19 & 0.238 & -1.31119 & .3285162 \\
\hline is_ninth & i & .7914921 & .4627248 & 1.71 & 0.089 & -.1236968 & 1.706681 \\
\hline is_2000 & | & .664683 & .7241504 & 0.92 & 0.360 & -.7675603 & 2.096926 \\
\hline is_2001 & | & .4249525 & .5872805 & 0.72 & 0.471 & -.7365859 & 1.586491 \\
\hline is_2002 & | & .7957991 & .5902797 & 1.35 & 0.180 & -.3716713 & 1.963269 \\
\hline is_2003 & i & .5891548 & .5868505 & 1.00 & 0.317 & -.5715332 & 1.749843 \\
\hline is_2004 & | & 1.074527 & 1.06552 & 1.01 & 0.315 & -1.032886 & 3.18194 \\
\hline is_2005 & i & .1275481 & .6014436 & 0.21 & 0.832 & -1.062002 & 1.317099 \\
\hline is_2006 & | & .1948479 & .648315 & 0.30 & 0.764 & -1.087406 & 1.477102 \\
\hline opinion_t _ 1 & 1 & .0605773 & .4543383 & 0.13 & 0.894 & -.8380246 & .9591792 \\
\hline opinion_t _2 & | & .7678648 & .4063181 & 1.89 & 0.061 & -.0357617 & 1.571491 \\
\hline opinion_t _-3 & i & -.6652421 & .6800506 & -0.98 & 0.330 & -2.010264 & .6797794 \\
\hline opinion_t _4 & | & .5398748 & .5496642 & 0.98 & 0.328 & -.5472652 & 1.627015 \\
\hline opinion_ty 5 & । & 1.335034 & .6567458 & 2.03 & 0.044 & .0361051 & 2.633962 \\
\hline opinion_ty $\sim 8$ & i & .5187196 & .8388363 & 0.62 & 0.537 & -1.140352 & 2.177792 \\
\hline opinion_ty $\sim 9$ & 1 & .7411527 & .6687079 & 1.11 & 0.270 & -.5814349 & 2.06374 \\
\hline _cons & | & -.2664151 & .8794255 & -0.30 & 0.762 & -2.005765 & 1.472935 \\
\hline
\end{tabular}

\section{Linear Regression with Weight Quotient as Dependent Variable (Table 16, Column 3)}

Linear regression

$\begin{array}{llr}\text { Number of obs } & = & 158 \\ \text { F }(23, \quad 134) & =2.17 \\ \text { Prob }>\text { F } & = & 0.0034 \\ \text { R-squared } & =0.2673 \\ \text { Root MSE } & =6.5402\end{array}$

\begin{tabular}{|c|c|c|c|c|c|c|c|}
\hline cir_sc_ip_ $\sim t$ & 1 & Coef. & $\begin{array}{l}\text { Robust } \\
\text { Std. Err. }\end{array}$ & t & $P>|t|$ & [95\% Conf. & Interval] \\
\hline is_patent & | & -2.048952 & 1.919208 & -1.07 & 0.288 & -5.844811 & 1.746907 \\
\hline is_pro_owner & | & -5.328769 & 2.157394 & -2.47 & 0.015 & -9.595718 & -1.06182 \\
\hline pro_patent & | & 6.026007 & 2.521344 & 2.39 & 0.018 & 1.039228 & 11.01279 \\
\hline judge & | & -.0086751 & .016527 & -0.52 & 0.601 & -.0413625 & .0240124 \\
\hline boyd_ideol y & i & 1.186234 & 1.229502 & 0.96 & 0.336 & -1.245506 & 3.617974 \\
\hline is_second & | & .9979585 & 2.227872 & 0.45 & 0.655 & -3.408385 & 5.404302 \\
\hline is_third & | & -1.358015 & 1.897409 & -0.72 & 0.475 & -5.11076 & 2.394731 \\
\hline is_seventh & i & 4.281528 & 2.320461 & 1.85 & 0.067 & -.3079402 & 8.870996 \\
\hline is_ninth & i & -1.460124 & 1.751971 & -0.83 & 0.406 & -4.925217 & 2.00497 \\
\hline is_2000 & | & -1.654926 & 3.320844 & -0.50 & 0.619 & -8.222976 & 4.913124 \\
\hline is_2001 & i & -1.280994 & 3.49389 & -0.37 & 0.714 & -8.191299 & 5.629312 \\
\hline is_2002 & i & -1.804201 & 3.385338 & -0.53 & 0.595 & -8.499809 & 4.891408 \\
\hline is_2003 & | & -1.63518 & 3.309028 & -0.49 & 0.622 & -8.17986 & 4.909501 \\
\hline is_2004 & | & 2.438509 & 3.741409 & 0.65 & 0.516 & -4.961345 & 9.838363 \\
\hline is_2005 & | & 2.666871 & 3.913064 & 0.68 & 0.497 & -5.072488 & 10.40623 \\
\hline is_2006 & 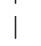 & .5232896 & 3.665999 & 0.14 & 0.887 & -6.727417 & 7.773996 \\
\hline
\end{tabular}




\begin{tabular}{|c|c|c|c|c|c|c|}
\hline opinion_t __1 & 2.160382 & 3.803619 & 0.57 & 0.571 & -5.362515 & 9.683278 \\
\hline opinion_t _2 & -2.611231 & 2.304846 & -1.13 & 0.259 & -7.169815 & 1.947353 \\
\hline opinion_t _3 & 1.294098 & 3.67111 & 0.35 & 0.725 & -5.966718 & 8.554915 \\
\hline opinion_t _4 & -.7516079 & 2.884062 & -0.26 & 0.795 & -6.455779 & 4.952563 \\
\hline opinion_ty $\sim$ & -1.53705 & 3.546139 & -0.43 & 0.665 & -8.550694 & 5.476595 \\
\hline opinion_ty $\sim 8$ & 2.519653 & 3.885638 & 0.65 & 0.518 & -5.165461 & 10.20477 \\
\hline opinion_ty $~ 9$ & -7.414957 & 3.043754 & -2.44 & 0.016 & -13.43497 & -1.394941 \\
\hline _cons & 9.925831 & 4.388391 & 2.26 & 0.025 & 1.246357 & 18.6053 \\
\hline
\end{tabular}

